INTERNATIONAL MONETARY FUND

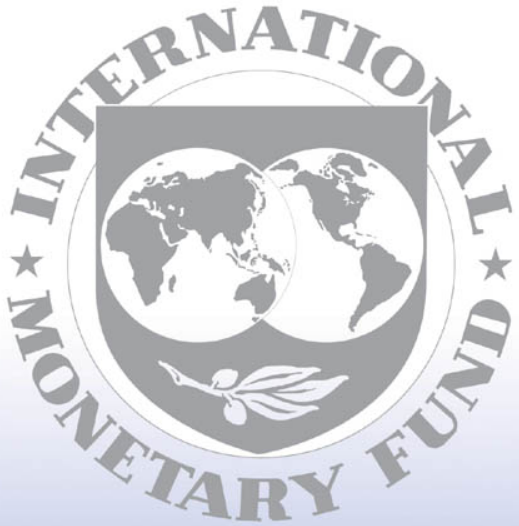

Staff

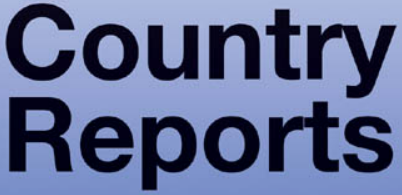




\section{Austria: Financial Sector Assessment Program Update Technical Note-Factual Update and Analysis of the IAIS Insurance Core Principles}

This technical note factual update of the IAIS Insurance Core Principles for Austria was prepared by a staff team of the International Monetary Fund as background documentation for the periodic consultation with the member country. It is based on the information available at the time it was completed in April 2008. The views expressed in this document are those of the staff team and do not necessarily reflect the views of the government of Austria or the Executive Board of the IMF.

The policy of publication of staff reports and other documents by the IMF allows for the deletion of market-sensitive information.

Copies of this report are available to the public from

International Monetary Fund $\bullet$ Publication Services

700 19th Street, N.W. • Washington, D.C. 20431

Telephone: (202) 623-7430 • Telefax: (202) 623-7201

E-mail: publications@imf.org • Internet: http://www.imf.org

Price: $\$ 18.00$ a copy

\section{International Monetary Fund Washington, D.C.}


This page intentionally left blank 
FINANCIAL SECTOR ASSESSMENT PROGRAM UPDATE AUSTRIA

\author{
TECHNICAL Note
}

FACTUAL UPDATE AND

ANALYSIS OF THE IAIS

INSURANCE CORE PRINCIPLES

APRIL 2008

INTERNATIONAL MONETARY FUND

MONETARY AND CAPITAL MARKETS DEPARTMENT 


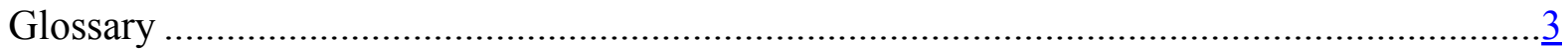

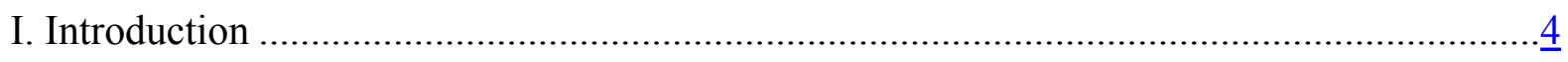

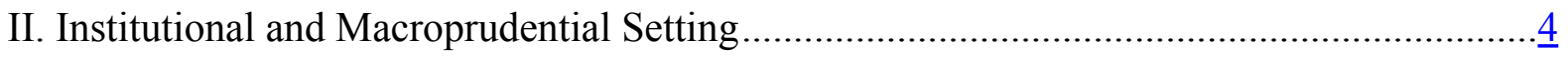

III. Implementation of IAIS Insurance Core Principles .....................................................

A. Conditions for Effective Insurance Supervision ..........................................

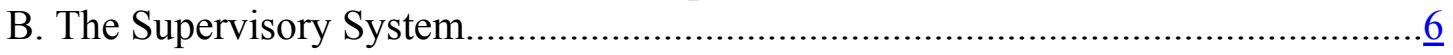

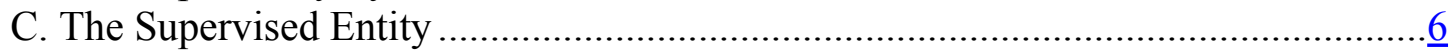

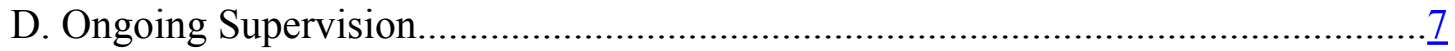

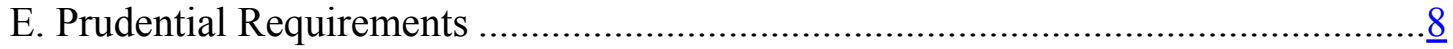

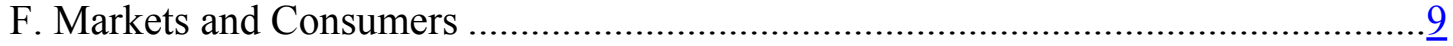

G. Anti-Money Laundering/Combating the Financing

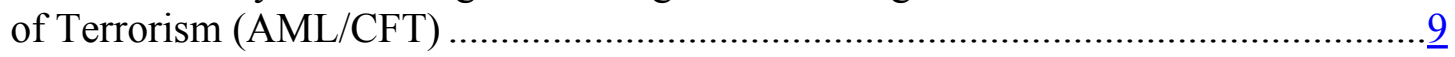

IV. Conclusions, Recommendations, and Authorities' Reactions ...................................... 9

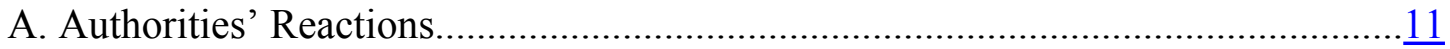




\section{GLOSSARY}

AML Anti-Money Laundering

CEIOPS Committee of European Insurance and Pensions

Supervisors

CESE Central, Eastern, and Southern European

CFT

Combating the Financing of Terrorism

EU

European Union

FMA

Financial Market Authority

FSAP

Financial Sector Assessment Program

IAIS

International Association of Insurance Supervisors

ICP

Insurance Core Principles

MoUs

OeNB

VAG

Memoranda of Understanding

Oesterreichische Nationalbank

VSE

Insurance Supervision Act

Vienna Stock Exchange 


\section{Factual Update and Analysis of the: IAIS Insurance Core Principles}

\section{INTRODUCTION}

1. A detailed assessment of observance of the International Association of Insurance Supervisors (IAIS) Insurance Core Principles (ICP) was undertaken in October 2003 as part of Austria's Financial Sector Assessment Program (FSAP). That assessment found that the regulatory framework and its implementation were generally of high standard and effective. Challenges related mainly to the expansion of Austrian companies into the Central, Eastern, and Southern European (CESE) region, and the prospective introduction of Solvency II requirements. The assessment concluded that efforts were needed to foster the development and role of the actuarial profession; strengthen corporate governance; enhance further supervision to ensure the early detection and correction of weaknesses; and facilitate the resolution of consumer inquiries and complaints.

2. This note provides a factual update and analysis of the regulatory regime for insurance companies in Austria in force in December 2007. Attention focuses on innovations since 2003: recent legal and regulatory changes are reviewed, and innovations in supervisory practice are described. The benchmark is the ICP, as revised in October 2003. The main sources of information included the Insurance Supervision Act (VAG), as amended, and other legislation; material provided by the Financial Market Authority (FMA), including a thorough self-assessment of observance of the ICP; and discussions during the FSAP Update mission in December 2007 with FMA staff and representatives of the insurance industry, who were generous with their time and consistently helpful and open. The IMF Austria FSAP Update team would like to express its appreciation of the efforts made in this connection by the authorities and especially the FMA Insurance and Pension Company Supervision Department.

\section{InStitutional AND MACROPRUdential SETting}

3. The FMA remains responsible for the regulation and supervision of the insurance sector and pension funds, along with other financial sector institutions and markets.

4. The Austrian economy generally performed well over the past several years, with growth above the euro-area average, falling unemployment, and low inflation. Opportunities in CESE countries contributed importantly to this outcome. In line with world trends, interest rates rose gradually. While the Vienna Stock Exchange (VSE) index increased sharply, real estate price inflation was moderate.

5. The structure of the domestic insurance sector has remained stable. At end-2006 there were 52 companies, of which 33 engaged wholly or mainly in life business; there are no independent reinsurance companies. Many individual companies are members of groups associated with banks, and two are linked to major insurers from another European country.

${ }^{1}$ Prepared by Daniel Hardy. 
Several foreign companies have branches in Austria, and Austrian companies have subsidiaries abroad, notably in CESE countries, where growth has been strong. The number of these subsidiaries rose from 58 in 2004 to 95 in 2007, and they contributed about 24 percent of premia written in 2006 for the relevant groups. In addition there were 60 small mutual associations, two of which are being wound down.

6. Life insurance companies offer in effect pension products, and compete with dedicated pension funds. There are 19 occupation-related pension funds. In 2003 the authorities introduced the Zukunftsvorsorge (provision for the future) to encourage private savings for retirement; Zukunftsvorsorge investments receive tax benefits and guaranteed principal (consideration is being given to allowing more flexible contracts).

Zukunftsvorsorge products are offered by insurance companies, staff provision funds and investment funds. There is also a mandatory employee protection fund (Mitarbeitervorsorgekasse), which mainly provides severance insurance.

7. Total insurance sector assets amounted to $€ 82$ billion at end-2006, equivalent to 32 percent of GDP. In addition, occupational pension funds held over $€ 12$ billion in assets, about $€ 1.8$ billion was in Zukunftsvorsorge funds, and about $€ 1.1$ billion in the Mitarbeitervorsorgekasse. The portfolio is concentrated in high-quality bonds, with relatively little allocated to real estate or equity. Companies have begun to invest in hedge funds and structured products, but the amounts involved are small. Solvency ratios have trended slowly upwards, profitability has been adequate (helped by dividends from subsidiaries in CESE countries), and operational efficiency has improved. Recently there has been no natural catastrophe as severe as the flood in 2002, although Austria is prone to certain other idiosyncratic natural events, such as damage from snow pressure.

\section{Implementation OF IAIS Insurance CoRe Principles}

\section{The FMA has continued to strengthen insurance sector regulation and}

supervision. It is aware that the main challenges identified in the 2003 assessment remain relevant, and is taking steps to meet them. Many of the specific recommendations of the 2003 assessment have been implemented, and the FMA has taken many other measures that reflect the changing role of the Austrian insurance sector in the region and European Union (EU) initiatives to strengthen integration and cooperation.

\section{A. Conditions for Effective Insurance Supervision}

9. The FMA issued a circular on the professional and personal qualifications of actuaries in 2004; the FMA has denied certification to some applicants due to lack of qualifications. A regulation on actuaries' reports was introduced in 2005. This regulation indicates the scope of reports and their structure. The Austrian Actuarial Association strengthened standards for chartered actuaries in 2005.

10. The availability of well-trained actuaries in sufficient numbers remains a constraint for insurance companies and their auditors. The prospective introduction of Solvency II requirements in 2012 will increase the incentive for companies to use more sophisticated techniques of risk assessment, and therefore increase demand for actuaries. Universities have 
begun to offer more and more comprehensive courses, but it will take time for supply to catch up with demand. Moreover, the requirements of International Financial Reporting Standards have increased demand for specialized accountants and auditors; a shortage of well-qualified staff is of some concern to the industry.

\section{B. The Supervisory System}

11. The number of insurance and pension fund supervisors has been increased. At the time of writing there were about 36 insurance supervisors and 4 pension fund supervisors, compared to 32 and 3, respectively, in 2003. There is an active training program. The insurance sector pays a levy to pay for supervision; the levy is capped by legislation, but the cap is currently far from binding. Nonetheless, human resources for supervision are strained by the need to prepare for the introduction of Solvency II, when considerable more effort and expertise will be needed to verify companies' own models and risk management systems.

\section{The FMA actively participates in the Committee of European Insurance and} Pensions Supervisors (CEIOPS), which was established in 2004, and cooperates in the implementation of various protocols. In this connection, the FMA is the lead supervisor for five Austrian companies with operations abroad, and is a member of the supervisory "college" for the foreign companies with operations in Austria. The exchange of information is reportedly satisfactory, although there may be scope for more joint analysis. The authorities have concluded a number of Memoranda of Understanding (MoUs) with countries, as needed (e.g., with Switzerland). MoUs with certain CESE countries became redundant when they joined the EU. Signature by Austria of the IAIS Multilateral MoU on information exchange is expected shortly. Bilateral contacts are maintained with supervisory authorities in those non-EU CESE countries with which an MoU has not yet been concluded and where Austrian companies are active. The first joint on-site inspection was recently undertaken.

\section{The Supervised Entity}

\section{Fit and proper criteria for supervisor board members and others have been}

strengthened. Following the recent amendment of legislation, which will come into force on January 1, 2008, the chairperson of a supervisory board of a financial institution with a gross written premium volume over $€ 500$ million is subject to a fit and proper test, which covers both probity and professional experience, including relevant sectoral expertise. The chairperson is required to report all relevant information to the supervisory board. The audit committee, which is a mandatory subcommittee of the supervisory board for all insurance companies with a gross written premium volume over $€ 750$ million, must include a financial/accounting expert (for which specific conditions are set). This person may be the chairperson him/herself, if he/she additionally fulfills the requirements stated for the financial expert. However, fit and proper tests are not applied to all supervisory board members. Fit and proper requirements for managers of insurance holding companies were introduced through an amendment of the VAG in 2004. 
14. Guidance on minimum standards for internal audit was introduced in 2005 to supplement the legal requirement to establish an audit department and appropriate internal controls. Financial companies are required to rotate external auditors every five years, but are not required to rotate audit firms (VAG amendment, 2005). A company's responsible actuary has to report to the executive board within five months of the end of the financial year, or if a serious deficiency is detected, and the report is passed to the FMA.

15. A number of measures have been taken to strengthen corporate governance more generally. The 2005 Stock Corporation Act requires that an audit committee has to be established for all listed companies and other larger corporations, with responsibility for preparation of the annual accounts. There are also provisions to limit conflicts of interest for supervisory board members and statutory auditors. All listed companies and insurance companies will be required to declare their adoption of a corporate governance framework from 2008. The Austrian Code of Corporate Governance, adherence to which is a precondition for listing on the primary market, was most recently reviewed in June 2007.

\section{Ongoing Supervision}

\section{Financial soundness and performance indicators of companies are regularly} compiled, and help determine priorities for on-site supervision and intensified monitoring. The frequency of reporting of many indicators has been increased from annual to quarterly (for example, on portfolio composition). A system has been established to communicate data among companies, the insurance association, and the FMA, and to generate a variety of quantitative and qualitative soundness indicators.

\section{Various indicators are collected for CESE countries in which Austrian} companies are active; the indicators include, for example, the market share of Austrian companies, the size and growth of the local insurance market, GDP growth rates, and country ratings. On this basis the FMA generates country vulnerability reports, which are combined with insurance group reports in deciding on a supervisory strategy for CESE exposures. If warning signs are detected, follow-up action may include close monitoring, intensified cooperation with host supervisors, and on-site inspections.

18. The FMA undertakes an increasing range of stress tests for insurance companies and pension funds; results of the stress testing help determine supervisory priorities. The scenarios encompass shocks both to asset values (for example, due to declines in equity and bond prices, or a deterioration in loan quality) and to some liabilities (for example, increase health insurance claims). Stress tests for longevity risk are not performed. However, the regulation on actuaries' reports requires actuaries to investigate the impact of adverse behavior of mortality assumptions and to report their findings to the FMA. Market-based indicators - such as distance to default measures and credit default swap rates - are not monitored, but they would be available for relatively few Austrian companies.

19. On-site supervision is becoming more frequent; 31 inspections were carried out in 2006 and 33 in 2007. There have recently been several targeted on-site inspections and follow-up visits, for example, on internal audit and risk-management systems; about 60 such visits were conducted in 2006. In 2006 the FMA performed its first joint on-site inspection of 
a foreign subsidiary of an Austrian insurance company, and more are planned. There has yet to be a joint on-site inspection of a foreign company hosted by Austria.

20. For the insurance companies that are organized into groups and/or have ownership links with banks, both stand-alone and consolidated supervision of groups are conducted; the FMA has a department devoted to consolidated supervision. The socalled EU conglomerates directive was transposed into national legislation in 2004. Financial groups are required to have group-wide risk management systems. Following the recent reorganization of bank supervision responsibilities, the FMA insurance supervisors will have to work still more closely with the Oesterreichische Nationalbank (OeNB) bank supervisors.

21. The FMA has extensive powers to require companies to take a range of corrective actions and to apply sanctions. For example, "recovery plans" for three companies were instituted in 2007, to ensure that their capital was increased to meet higher minimum absolute capital requirements. In 2006, the Administrative Court approved an injunction on the tariff of a life insurance contract that was out of line with actuarial projections, and the correction of a pension fund contract that contained provisions inconsistent with regulations on employers' contributions.

\section{E. Prudential Requirements}

22. Provisions on the calculation of technical and mathematical reserves are amended from time to time. The maximum interest rate for the calculation of life insurance provisions was most recently amended with effect on January 1, 2006, when it was reduced to 2.25 percent from 2.75 percent. Furthermore the FMA requires insurance companies to adopt the current annuity table (AVÖ $2005 \mathrm{R}$ ) for the calculation of new annuity contracts and to strengthen reserves of existing annuity contracts accordingly. A regulation issued in 2005 requires that policyholders' participation in profits or the refund of premia in life and health insurance amount to at least 85 percent of the assessment base.

23. For the Zukunftsvorsorge, providers need to submit to the FMA details of the model used in the control and management of risks relative to their actuarial obligations. The model must be evaluated by an outside expert and certified by the responsible actuary. Additional technical provisions must be made when investment risk on Zukunftsvorsorge contracts is greater than that on ordinary life insurance (for example, because of the principal guarantee).

\section{Investment policy for insurance contracts is governed by a number of} regulations, notably the Kapitalanlageverordnung, which was last amended in 2007, and the regulations on assets covering technical provisions, which were last amended in 2006. The regulations contain a variety of limits on asset shares, liquidity, etc. Derivatives may be used by insurance companies only in connection with the hedging of asset positions, and short positions are prohibited. Hedge fund investments are limited to 7 percent of the portfolio for insurance companies. Legislation on investment by pension companies was passed in 2005, and implementing regulations took effect in 2006. Their investments must either be guided by procedures in compliance with risk management regulations with a few 
caps on certain types of investment, or abide by simpler but more restrictive quantitative restrictions; currently, no fund has opted for the quantitative restrictions.

25. It is expected that a "prudent person rule"-which has applied to pension companies already since 2006 - will also be introduced for insurance companies in 2012 as a result of Solvency II. The FMA is aware that the greater freedom granted companies under a "prudent person rule" will require yet closer supervision of risk management systems and consumer protection.

26. There have been some amendments to prudential requirements applied to reinsurers, who have always been covered by the regulatory framework. In particular, since 2007, reinsurers are required to cover technical provisions by admissible assets. The adequacy of reinsurance arrangements, including the financial strength of reinsurers used by Austrian companies, is monitored as part of the FMA's supervision.

\section{F. Markets and Consumers}

27. The FMA supervises only bank intermediaries of insurance and pension products. The Federal Ministry of Economics and Labor has general authority over intermediaries, to which end it makes use of local administrative authorities. It should be noted that the maximum fine in case of illicit activity by an intermediary is only $€ 3,600$. The 2002 EU Insurance Mediation Directive was implemented in 2005 through amendment of the Trade Act, which introduced indemnity insurance for brokers, and information duties. The amendment 2005 of the Maklergesetz (the law on agents) introduced strictly segregated client accounts. A review of the Insurance Mediation Directive is planned for 2008.

28. Various laws contain provisions on consumer protection. Requirements to disclose the relationship between the intermediary and the relevant insurance company were strengthened in the 2005 amendment of the Trade Act, which implemented the EU Insurance Mediation Directive. However, there seem to be relatively limited requirements to disclose and explain fully all fees and expected returns associated with savings products such as pension plans.

\section{G. Anti-Money Laundering/Combating the Financing of Terrorism (AML/CFT)}

29. Legislation implementing the third EU AML Directive is currently before parliament. In 2008 a full review of all issues on AML/CFT based on the Financial Sector Action Task Force 40+9 Methodology will be conducted in collaboration with the IMF.

\section{Conclusions, Recommendations, And Authorities' Reactions}

30. The regulation and supervision of the insurance sector and the associated pension sector continues to evolve with the market. New products have been introduced, companies are adopting more complex investment strategies, and cross-border linkages have intensified. A few episodes of managerial failure in other financial sectors have highlighted the importance of effective corporate governance. The authorities should be commended for reacting promptly to these developments, building on a strong base. 


\section{The authorities are aware of a number of areas in which further strengthening is required, even if they go beyond the ICP:}

- The prospective introduction of the Solvency II regime and the growth of the pension sector will require that the FMA enhance the size and, in particular, the relevant expertise of its staff. To this end, adequate resources will have to be provided. Cooperation with the industry itself, professional organizations, and universities will be helpful.

- Consideration should be given to extending "fit and proper" requirements to some supervisory board members besides the chairman, at least in larger companies.

- Consideration should be given to requiring the responsible actuary to present his/her report to the supervisory board and not just the executive board, and to do so immediately if it is discovered that the company's policies grossly contravene sound actuarial principles. This requirement would parallel that applicable to auditors.

- The FMA should extend its stress testing of insurance companies' and pension funds' liabilities. Specifically, longevity risk should be addressed. While demographic pressures in Austria do not appear to be as acute as in some other industrialized countries, longevity risk must be viewed as a major concern.

- The FMA should investigate the use of market-based soundness indicators, such as distance to default measures and credit default swap rates - where available - to supplement its balance sheet-based soundness indicators.

- The FMA's plans to conduct more on-site inspections, especially in Austrian companies' subsidiaries abroad, are well justified. The home supervisors of foreign companies operating in Austria could perhaps be invited to participate in on-site inspections in order to strengthen the coordination of analysis.

- Following the recent reorganization of bank supervision responsibilities, the FMA insurance supervisors will need to work even closer with the OeNB in supervising financial groups.

- The FMA should keep under review guidelines on asset allocation by insurance companies and elaborate supervision methods in this area, in parallel to the move toward full application of the "prudent person rule." Companies currently make limited use of alternative investments, such as high-yield bonds, asset-backed securities, and hedge funds, but they may become more adventurous (especially if returns on conventional investments return to very low levels); the new investments may not be well understood by clients or even the companies' own management.

- Maximum fines should be increased to the maximum allowable under administrative law; insurance and pension transactions may involve large sums, and correspondingly the deterrents for misdeeds need to be substantial. 
- The FMA should remain vigilant for attempts by companies and intermediaries to circumvent provisions on the disclosure to clients of potential returns, risks, and fees. While existing regulations contain extensive protections in this area, experience elsewhere suggests that companies and intermediaries may find innovative ways to hide costs.

\section{A. Authorities' Reactions}

32. The Austrian Ministry of Finance and the FMA consider the recommendations as very valuable and in general in line with their own assessments and priorities for the forthcoming years.

33. We fully agree that, among others, the introduction of the Solvency II regime and the growth of the pension sector will require enhancement of size and expertise of the supervisory staff in order to maintain the effectiveness of insurance and pension supervision. We are aware that the implementation of Solvency II will certainly pose significant challenges to the FMA in the near future. In particular, the FMA will also continue to closely monitor insurance companies' asset allocation, further develop the stress testing and keep monitoring the implementation of disclosure rules.

34. More specifically, the Austrian authorities would like to put forward the following comments:

Para. 31, Bullet Point 7: The FMA notes that Conglomerate Supervision has, in line with its characterization as supplementary supervision to insurance and banking group supervision, since 2004 been organized in such a way that supervision - based upon sectoral (banking and insurance) analysis - is coordinated and effected under the responsibility of a cross-sector unit (IV/1 Integrierte Finanzmärkte) within the FMA and is performed through the cooperation of all competent staff, including insurance supervisors, within a supervisory team. The new situation will entail the inclusion of competent banking group analysts from OeNB as a source of information in addition to the current constituency of these supervisory teams. 